\title{
Selective hydrogenation of phenol to cyclohexanone in water over Pd catalysts supported on Amberlyst-45
}

\author{
Mengsi Zhao, Juanjuan Shi, Zhaoyin Hou * \\ Institute of Catalysis, Department of Chemistry, Zhejiang University, Hangzhou 310028, Zhejiang, China
}

\section{A R T I C L E I N F O}

Article history:

Received 3 September 2015

Accepted 29 September 2015

Published 5 February 2016

Keywords:

Phenol

Hydrogenation

Cyclohexanone

Palladium

Amberlyst-45 resin

Supported catalyst

\section{A B S T R A C T}

A series of $\mathrm{Pd}$ catalysts were prepared on different supports $\left(\mathrm{Fe}_{2} \mathrm{O}_{3}, \mathrm{SiO}_{2}, \mathrm{ZnO}, \mathrm{MgO}, \mathrm{Al}_{2} \mathrm{O}_{3}\right.$, carbon, and Amberlyst-45) and used in the selective hydrogenation of phenol to cyclohexanone in water. The Amberlyst-45 supported Pd catalyst (Pd/A-45) was highly active and selective under mild conditions $\left(40-100{ }^{\circ} \mathrm{C}, 0.2-1 \mathrm{MPa}\right)$, giving a selectivity of cyclohexanone higher than $89 \%$ even at complete conversion of phenol. Experiments with different Pd loadings (or different particle sizes) confirmed that the formation of cyclohexanone was a structure sensitive reaction, and Pd particles of 12-14 nm on Amberlyst-45 gave better selectivity and stability.

(C) 2016, Dalian Institute of Chemical Physics, Chinese Academy of Sciences. Published by Elsevier B.V. All rights reserved.

\section{Introduction}

Cyclohexanone is an important organic compound in the manufacture of nylon. Cyclohexanone is produced by the selective oxidation of cyclohexane in air over cobalt catalysts [1-4]. Alternatively, cyclohexanone can also be synthesized by the selective hydrogenation of phenol, but this requires high temperature and gives several byproducts such as cyclohexanol and cyclohexane [2,3]. Ways to increase the selectivity to cyclohexanone have been much studied in recent years [5-7]. Several catalysts including Pd [8-12], Pt [13,14], Rh [15], and Ni $[16,17]$ catalysts were reported frequently, and Pd-based catalysts are favored for this reaction for its high activity and selectivity. At the same time, many supports, including $\mathrm{NaY}$ zeolite [1], carbon [18], hydrophilic carbon [19], Mg0 [20], $\mathrm{Fe}_{2} \mathrm{O}_{3}$ [20], mesoporous $\mathrm{CeO}_{2}$ [21], HZSM-5 [22], metal organic frameworks (MOFs) [23,24], $\mathrm{SiO}_{2}, \gamma-\mathrm{Al}_{2} \mathrm{O}_{3} \quad[25,26]$, and mpg- $\mathrm{C}_{3} \mathrm{~N}_{4}[5,27]$, have been used as the support of $\mathrm{Pd}$. The product distribution depends on both the active metal and support, and a co-added acid or acidity of the catalyst can improve the conversion of phenol [1,28]. However, achieving a high selectivity of cyclohexanone (>90\%) at high phenol conversion ( $>80 \%$ ) with a single catalyst remains challenging.

An ion exchange resin is a porous, insoluble matrix with a high surface area. It is widely used in catalysis for its strong acidity. The Amberlyst-45 resin (A-45) is a new macroporous polymer designed for use at high temperature. It is made of polystyrene sulfonate and its concentration of acid sites can reach $2.95 \mathrm{eq} / \mathrm{kg}$. In this work, Pd nanoparticles (NPs) were loaded on A-45 by a facile routine, and this $\mathrm{Pd} / \mathrm{A}-45$ catalyst was used in the selective hydrogenation of phenol to cyclohexanone in water.

\footnotetext{
* Corresponding author. Tel/Fax: +86-571-88273283; E-mail: zyhou@zju.edu.cn

This work was supported by the National Natural Science Foundation of China $(21473155,21273198,21073159)$ and the Natural Science Foundation of Zhejiang Province (LZ12B03001).
} 


\section{Experimental}

\subsection{Catalyst preparation}

Commercial resin Amberlyst-45 (A-45, Dow Chemical Company) was purchased from Sigma Co. (China Branch). It was washed with distilled water 3 times and dried in vacuum at 50 ${ }^{\circ} \mathrm{C}$ for $12 \mathrm{~h}$ before use. First, $1.0 \mathrm{~g}$ of A-45 was immersed in an aqueous solution of $\mathrm{PdCl}_{2}(30 \mathrm{~mL}$, containing a controlled amount of Pd) under stirring at $50{ }^{\circ} \mathrm{C}$ for $24 \mathrm{~h}$. Then, the solid particles were separated by filtration, washed with a mixed solution of ethanol/water (1:1 by volume) until free of $\mathrm{Cl}^{-}$, and further dried under vacuum at $50{ }^{\circ} \mathrm{C}$ for $12 \mathrm{~h}$. Finally, the dried solid was pretreated in a flow of $\mathrm{H}_{2}$ at $120^{\circ} \mathrm{C}$ for $1.0 \mathrm{~h}$ before the catalytic reaction. These catalysts were denoted as $\operatorname{Pd}(x) / A-45$, where $x w t \%$ is the loading of $\mathrm{Pd}$.

As references, $\mathrm{Fe}_{2} \mathrm{O}_{3}, \mathrm{SiO}_{2}, \mathrm{ZnO}, \mathrm{MgO}, \mathrm{Al}_{2} \mathrm{O}_{3}$, and active carbon (AC) supported Pd catalysts were also prepared by an impregnation method described elsewhere [29]. Before impregnation, the support was first calcined at $500{ }^{\circ} \mathrm{C}$ in $\mathrm{N}_{2}$ flow for 4 $\mathrm{h}$ and then impregnated with an aqueous solution of $\mathrm{PdCl}_{2}$ with equal weight ratio of $\mathrm{Pd}$ and support. The precursor was dried in $\mathrm{N}_{2}$ at $110{ }^{\circ} \mathrm{C}$ overnight followed by calcination in $\mathrm{N}_{2}$ at $500{ }^{\circ} \mathrm{C}$ for $4 \mathrm{~h}$. Before the catalytic reaction, the catalyst was reduced in $\mathrm{H}_{2}$ at $120^{\circ} \mathrm{C}$ for $1 \mathrm{~h}$.

The loading of $\mathrm{Pd}$ on the above catalysts was checked by inductively coupled plasma atomic emission spectroscopy (ICP, Plasma-Spec-II spectrometer). The results are summarized in Table 1.

\subsection{Catalyst characterization}

X-ray diffraction (XRD) patterns were performed on a Rigaku D/MAX 2550/PC diffractometer (18 kW) at $40 \mathrm{kV}$ and $100 \mathrm{~mA}$ with $\mathrm{Cu} K_{\alpha}$ radiation $(\lambda=1.5406 \AA)$ in the range of $5^{\circ}-80^{\circ}$. The surface area of the catalysts was measured by $\mathrm{N}_{2}$ adsorption using an ASAP 2010 analyzer (Micromeritics) after pretreatment at $100{ }^{\circ} \mathrm{C}$ for $4 \mathrm{~h}$ under vacuum. X-ray photoelectron spectra (XPS) were recorded on a Perkin-Elmer PHI ESCA System. The X-ray source was an Mg standard anode (1253.6 $\mathrm{eV}$ ) at $12 \mathrm{kV}$ and $300 \mathrm{~W}$. Transmission electron microscopy (TEM) images were obtained using an accelerating voltage of

Table 1

Physical properties of the catalysts.

\begin{tabular}{lccr}
\hline Catalyst & $\begin{array}{c}\text { Pd loading } \\
(\mathrm{wt} \%)\end{array}$ & $\begin{array}{r}\text { Particle size of } \mathrm{Pd}^{\mathrm{b}} \\
(\mathrm{nm})\end{array}$ & $\begin{array}{c}\text { Surface area } \\
\left(\mathrm{m}^{2} / \mathrm{g}\right)\end{array}$ \\
\hline $\mathrm{Pd} / \mathrm{Fe}_{3} \mathrm{O}_{4}$ & 2.5 & 5.5 & 9.2 \\
$\mathrm{Pd} / \mathrm{SiO}_{2}$ & 2.7 & 7.4 & 289.3 \\
$\mathrm{Pd} / \mathrm{ZnO}$ & 2.8 & 10.1 & 14.7 \\
$\mathrm{Pd} / \mathrm{MgO}$ & 2.8 & 8.0 & 39.4 \\
$\mathrm{Pd} / \mathrm{Al}_{2} \mathrm{O}_{3}$ & 2.6 & 4.5 & 156.2 \\
$\mathrm{Pd} / \mathrm{AC}$ & 2.9 & 6.6 & 1396.0 \\
$\mathrm{Pd}(0.9) / \mathrm{A}-45$ & 0.9 & 9.0 & 40.3 \\
$\mathrm{Pd}(2.7) / \mathrm{A}-45$ & 2.7 & 12.0 & 39.8 \\
$\mathrm{Pd}(4.5) / \mathrm{A}-45$ & 4.5 & 14.5 & 38.0 \\
\hline
\end{tabular}

a Measured by ICP.

b Calculated using Scherrer's equation.

${ }^{c}$ Measured by $\mathrm{N}_{2}$ adsorption.
200 kV (TEM, JEOL-2010F).

\subsection{Hydrogenation of phenol}

The hydrogenation of phenol was carried out in a $50 \mathrm{~mL}$ custom designed stainless steel autoclave with a Teflon inner layer. In a typical reaction, a controlled amount of catalyst was dispersed in $20 \mathrm{~mL}$ aqueous solution of phenol. Then, the reactor was sealed, purged with purified hydrogen 5 times, and pressurized to the desired pressure. The reactor was heated in an oil bath and stirred with a magnetic stirrer (MAG-NEO, RV-06M, Japan). After reaction, the solid catalyst was separated by centrifugation. The liquid reaction mixture was analyzed by a gas chromatograph (HP 5890, USA) with a 30 m capillary column (HP-5) using a flame ionization detector. All products were confirmed by GC-MS (Agilent 6890-5973N). For each successive use, the catalyst was washed with water three times and dried under vacuum at $40{ }^{\circ} \mathrm{C}$ for $6 \mathrm{~h}$. The conversion of phenol and selectivity for cyclohexanone (and cyclohexanol) were calculated as:

$$
\begin{aligned}
& \text { Conversion }=(\text { phenoladded-mol }- \text { phenol } \text { remain-mol }) \\
& / \text { phenol }_{\text {added-mol }} \times 100 \% \\
& \text { Selectivity }=\text { cyclohexanone } \text { formed-mol }_{\text {f }} /\left(\text { phenol }_{\text {added-mol }}\right. \\
& \text { - phenol }{ }_{\text {remain-mol }} \times 100 \%
\end{aligned}
$$

\section{Results and discussion}

\subsection{Characterization of the catalysts}

Figure 1 shows the XRD patterns of the pristine A-45 resin and Pd/A-45 catalysts with different loadings of Pd. Only a broad peak of amorphous carbon appeared with A-45. Beside the peak of amorphous carbon, four characteristic diffraction peaks of $\mathrm{Pd}$ were detected at $40.0^{\circ}, 46.5^{\circ}, 68.1^{\circ}$, and $82.1^{\circ}$ with all the Pd/A-45 catalysts, which corresponded to the (111), (200), (220), and (311) crystalline planes of face centered cubic of Pd (JCPDS 46-1043). The crystalline size of Pd was calculated from the half-width of the $\operatorname{Pd}(111)$ peak using the Scherrer equation. The results are summarized in Table 1 . The particle size of Pd on A-45 increased from $9.0 \mathrm{~nm}$ (in $\mathrm{Pd}(0.9) / \mathrm{A}-45)$ to

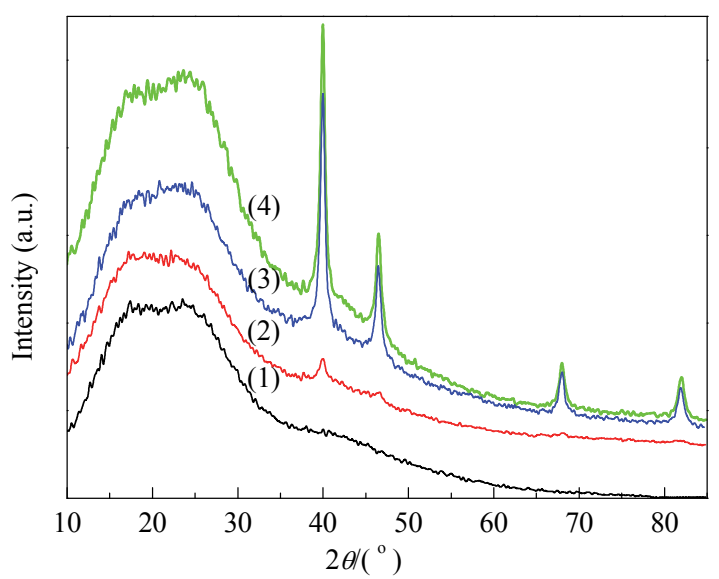

Fig. 1. XRD patterns of $A-45$ (1), $\operatorname{Pd}(0.9) / A-45$ (2), $\operatorname{Pd}(2.7) / A-45$ (3), and $\mathrm{Pd}(4.5) / \mathrm{A}-45$ (4). 
$14.5 \mathrm{~nm}$ (in Pd(4.5)/A-45) with increasing Pd loading.

Figure 2 shows typical TEM images and the histogram of the Pd particle size distribution of the $\mathrm{Pd}(2.7) / \mathrm{A}-45$ catalyst. $\mathrm{Pd}$ particles were dispersed mainly in the macropore channels of A-45, and the particles of Pd were in the range of 5-20 nm. The calculated mean particle size of the counted particles was 12.2 $\mathrm{nm}$, which agreed with the XRD results.

Figure 3 presents the XPS spectra of pristine A-45 and the $\mathrm{Pd}(2.7) / \mathrm{A}-45$ catalyst. The binding energy and surface content of $\mathrm{C}, \mathrm{S}, \mathrm{O}$, and $\mathrm{Pd}$ are summarized in Table 2. The binding energy confirmed that plentiful $-\mathrm{SO}_{3} \mathrm{H}(168.9 \mathrm{eV})$ groups existed on the surface of pristine A-45 [30,31]. When Pd was loaded, the surface composition of A-45 remained stable, and mainly metallic Pd was formed after reduction [32].

\subsection{Catalytic reaction}

First, the selective hydrogenation of phenol to cyclohexa-
Table 2

Surface composition of the $\mathrm{Pd}(2.7) / \mathrm{A}-45$ catalyst.

\begin{tabular}{lcccccccc}
\hline \multirow{2}{*}{ Sample } & \multicolumn{3}{c}{ Binding energy $(\mathrm{eV})$} & & \multicolumn{5}{c}{ Surface content (wt\%) } \\
\cline { 2 - 4 } \cline { 7 - 9 } & $\mathrm{Pd}$ & $\mathrm{C}$ & $\mathrm{S}$ & & $\mathrm{Pd}$ & $\mathrm{C}$ & $\mathrm{S}$ & $\mathrm{O}$ \\
\hline $\mathrm{A}-45$ & - & 284.40 & 168.89 & & - & 79.38 & 5.13 & 15.49 \\
$\mathrm{Pd}(2.7) / \mathrm{A}-45$ & 335.74 & 284.32 & 168.45 & & 3.98 & 76.30 & 4.92 & 14.80 \\
& 340.81 & & & & & & \\
\hline
\end{tabular}

none was performed over the different catalysts in water at $100{ }^{\circ} \mathrm{C}$ for $3 \mathrm{~h}$ (Table 3). All the tested catalysts were active for this reaction. Cyclohexanone and cyclohexanol were the only reaction products observed over the entire range of conditions studied. The conversion of phenol increased in the order of $\mathrm{Pd} / \mathrm{Fe}_{3} \mathrm{O}_{4}, \mathrm{Pd} / \mathrm{SiO}_{2}, \mathrm{Pd} / \mathrm{ZnO}, \mathrm{Pd} / \mathrm{MgO}$, and $\mathrm{Pd} / \mathrm{Al}_{2} \mathrm{O}_{3}$. Only mainly the byproduct cyclohexanol was formed over $\mathrm{Pd} / \mathrm{MgO}$, $\mathrm{Pd} / \mathrm{ZnO}$, and $\mathrm{Pd} / \mathrm{Fe}_{3} \mathrm{O}_{4}$. On the other hand, $\mathrm{Pd} / \mathrm{AC}$ and $\mathrm{Pd}(2.7) / \mathrm{A}-45$ were more active than the oxide supported $\mathrm{Pd}$ catalysts. Phenol was converted completely over $\mathrm{Pd}(2.7) / \mathrm{A}-45$

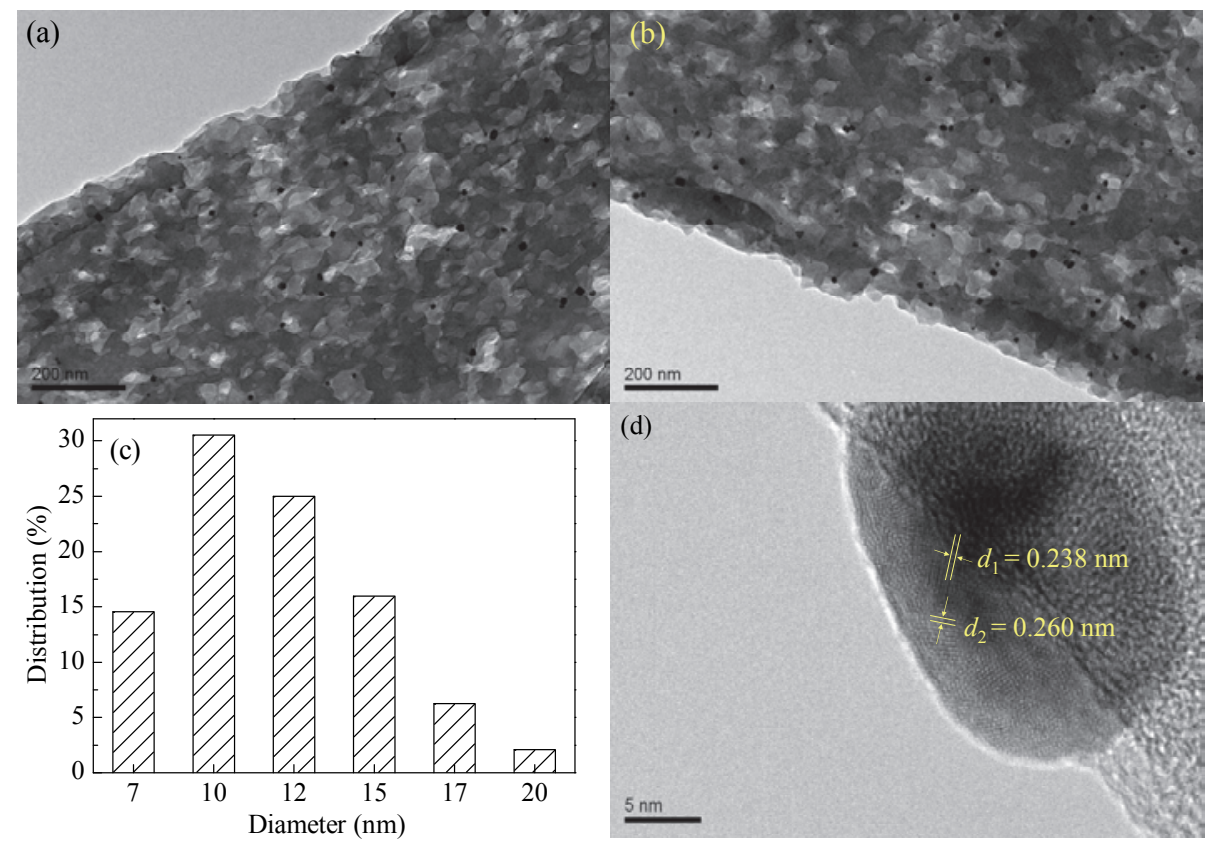

Fig. 2. (a, b) TEM images of Pd(2.7)/A-45; (c) Histogram of Pd particle size distribution in Pd(2.7)/A-45; (d) High resolution TEM image of Pd nanoparticles in $\operatorname{Pd}(2.7) / A-45$.
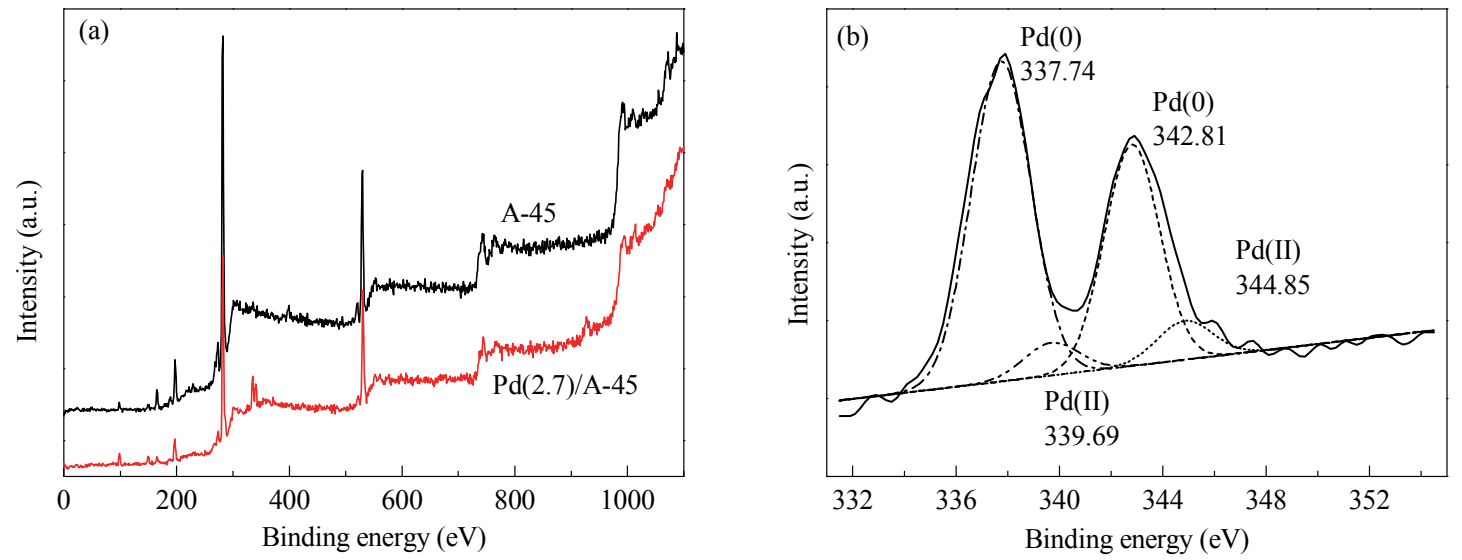

Fig. 3. XPS spectra of $\mathrm{A}-45$ and $\mathrm{Pd}(2.7) / \mathrm{A}-45$ (a), and the $\mathrm{Pd} 3 d$ in $\mathrm{Pd}(2.7) / \mathrm{A}-45$ (b). 
Table 3

Hydrogenation of phenol over the different catalysts.

\begin{tabular}{|c|c|c|c|c|}
\hline \multirow{2}{*}{ Entry } & \multirow{2}{*}{ Catalyst } & \multirow{2}{*}{$\begin{array}{c}\text { Conversion } \\
(\%)\end{array}$} & \multicolumn{2}{|c|}{ Selectivity (\%) } \\
\hline & & & Cyclohexanone & Cyclohexanol \\
\hline 1 & blank & 0 & - & - \\
\hline 2 & $\mathrm{Pd} / \mathrm{Fe}_{3} \mathrm{O}_{4}$ & 14.7 & 32.2 & 67.8 \\
\hline 3 & $\mathrm{Pd} / \mathrm{SiO}_{2}$ & 26.6 & $>99.0$ & - \\
\hline 4 & $\mathrm{Pd} / \mathrm{ZnO}$ & 27.7 & 26.1 & 74.0 \\
\hline 5 & $\mathrm{Pd} / \mathrm{MgO}$ & 35.0 & 17.7 & 82.3 \\
\hline 6 & $\mathrm{Pd} / \mathrm{Al}_{2} \mathrm{O}_{3}$ & 87.5 & 65.1 & 34.9 \\
\hline $7^{\text {a }}$ & $\mathrm{Pd} / \mathrm{AC}$ & 69.1 & 62.4 & 37.6 \\
\hline $8^{\text {a }}$ & $\mathrm{Pd}(2.7) / \mathrm{A}-45$ & 100.0 & 89.0 & 11.0 \\
\hline 9 & A- 45 & 0 & - & - \\
\hline
\end{tabular}

Reaction conditions: phenol $0.5 \mathrm{mmol}$, water $20 \mathrm{~mL}$, phenol/Pd ratio 8.0, $100{ }^{\circ} \mathrm{C}, 3 \mathrm{~h}, \mathrm{H}_{2} 1.0 \mathrm{MPa}, 1000 \mathrm{r} / \mathrm{min}$. a $0.5 \mathrm{~h}$.

even for $0.5 \mathrm{~h}$, and the selectivity for cyclohexanone reached $89.0 \%$. These results suggested that the ion exchanged resin (A-45) was a good support for the selective hydrogenation of phenol to cyclohexanone.

The good performance of $\mathrm{Pd}(2.7) / \mathrm{A}-45$ was confirmed under various reaction conditions (Table 4 and Fig. 4). The conversion of phenol increased quickly from $23.8 \%$ (at $40{ }^{\circ} \mathrm{C}$ ) to $100 \%$ (at $100{ }^{\circ} \mathrm{C}$ ) with rising temperature, while the selectivity for cyclohexanone only decreased slightly from $92.4 \%$ to $89.0 \%$ (Table 4). At the same time, it was confirmed that a low pressure was more favorable for the formation of cyclohexanone and the selectivity for cyclohexanone reached $95.6 \%$ at $0.2 \mathrm{MPa}$. More importantly, the selectivity for cyclohexanone remained higher than $89.0 \%$ in a wide range of phenol/Pd ratio in the feed at $100{ }^{\circ} \mathrm{C}$ and $1.0 \mathrm{MPa}$ (Fig. 4). The performance of the $\mathrm{Pd}(2.7) / \mathrm{A}-45$ catalyst was lower than that of $\mathrm{Pd} / \mathrm{C}+\mathrm{AlCl}_{3}$ [1] and mpg- $\mathrm{C}_{3} \mathrm{~N}_{4}$ supported $\mathrm{Pd}$ [27], but it was better than those of active carbon, hydrophilic carbon, and $\mathrm{Al}_{2} \mathrm{O}_{3}$ supported $\mathrm{Pd}$ catalysts [19], and the selectivity for cyclohexanone was higher than that of $\mathrm{Pd} / \mathrm{C}$ [33].

The published work [1,21-28] suggested that the selectivity for cyclohexanone in phenol hydrogenation depended on the adsorption mode of phenol, and the nonplanar form of adsorbed phenol was more favorable for the formation of cyclohexanone than a coplanar form of adsorbed molecule [21]. Wang et al. [27] further disclosed that the acid sites on the surface of the catalyst helped the nonplanar form adsorption of phenol through the hydroxy group forming strong $\mathrm{O}-\mathrm{H} \cdots \pi$ interactions. Therefore, we think that the good performance of $\mathrm{Pd}(2.7) / \mathrm{A}-45$ can be attributed to its strong acidity $(2.95$

Table 4

Performance of $\mathrm{Pd}(2.7) / \mathrm{A}-45$ at different temperatures and pressures.

\begin{tabular}{|c|c|c|c|c|}
\hline \multirow{2}{*}{$\begin{array}{l}\text { Temperature } \\
\left({ }^{\circ} \mathrm{C}\right)\end{array}$} & \multirow{2}{*}{$\begin{array}{c}\mathrm{H}_{2} \text { pressure } \\
(\mathrm{MPa})\end{array}$} & \multirow{2}{*}{$\begin{array}{c}\text { Conversion } \\
(\%)\end{array}$} & \multicolumn{2}{|c|}{ Selectivity (\%) } \\
\hline & & & Cyclohexanone & Cyclohexanol \\
\hline$\overline{40}$ & 1.0 & 23.8 & 92.4 & 7.6 \\
\hline 60 & 1.0 & 60.2 & 91.0 & 9.0 \\
\hline 80 & 1.0 & 84.5 & 90.0 & 10.0 \\
\hline 100 & 1.0 & 100.0 & 89.0 & 11.0 \\
\hline 100 & 0.5 & 52.3 & 91.8 & 8.2 \\
\hline 100 & 0.2 & 21.7 & 95.6 & 4.4 \\
\hline
\end{tabular}

Reaction conditions: phenol $0.5 \mathrm{mmol}$, water $20 \mathrm{~mL}$, phenol/Pd ratio $8.0,1000 \mathrm{r} / \mathrm{min}, 0.5 \mathrm{~h}$.

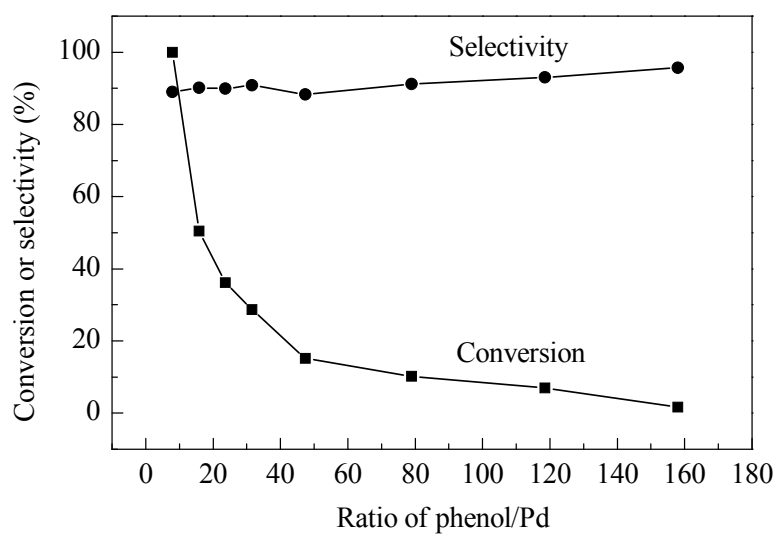

Fig. 4. Performance of $\mathrm{Pd}(2.7) / \mathrm{A}-45$ for different phenol/Pd ratios in the feed. Reaction conditions: $100^{\circ} \mathrm{C}, \mathrm{H}_{2} 1.0 \mathrm{MPa}, 0.5 \mathrm{~h}$.

mmol/g in A-45). At the same time, the acid sites also enrich the electron density of Pd, enhance the desorption of phenoxy species [28], and inhibit further hydrogenation of the intermediate product [1].

The recycle experiments also indicated that $\mathrm{Pd} / \mathrm{A}-45$ showed a better performance in reusability (Fig. 5). $\mathrm{Pd}(2.7) / \mathrm{A}-45$ could be reused at least 6 times without significant loss of activity, maintaining at least $46.6 \%$ conversion, which is a prerequisite for practical application. It is important to highlight that the selectivity for cyclohexanone remained high (about 90\%) and comparable to that of the fresh catalyst. XRD analysis of a spent $\mathrm{Pd}(2.7) / \mathrm{A}-45$ catalyst indicated that the particle size of Pd was increased slightly from 12.0 to $13.6 \mathrm{~nm}$ (Fig. 6), and the decreased conversion of phenol can be attributed to the sintering of Pd. Another possible reason for activity loss may be due to the swelling of the polymer resin in the polar solvent and/or reactants [34], or because the resin beads were gradually mechanically damaged by being vigorously stirred with a magnetic stirrer bar during the reaction [35].

As Pd(2.7)/A-45 with a similar loading amount of Pd exhibited the best performance among the tested catalysts (Table 3),

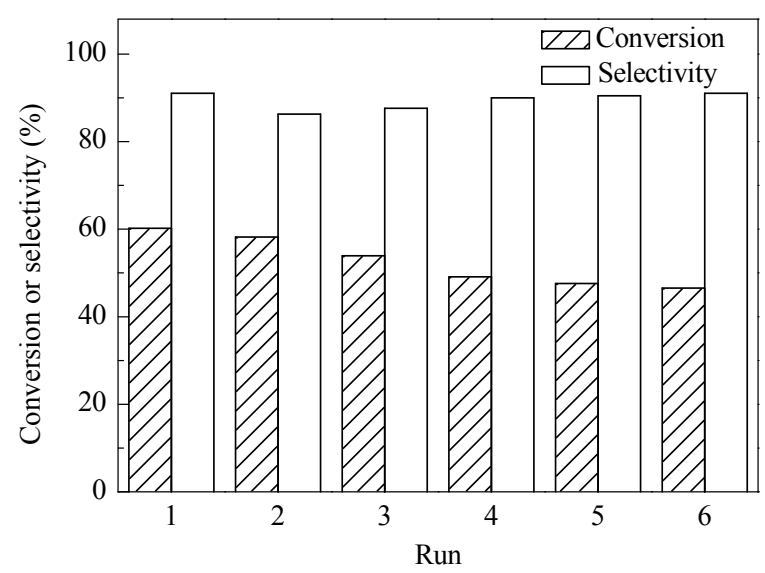

Fig. 5. Recycling of $\mathrm{Pd}(2.7) / \mathrm{A}-45$ for phenol hydrogenation. Reaction conditions: $0.24 \mathrm{~g} \mathrm{Pd}(2.7) / \mathrm{A}-45$ in the first run (no further addition), $0.5 \mathrm{mmol}$ phenol in each run, $60^{\circ} \mathrm{C}, \mathrm{H}_{2} 1.0 \mathrm{MPa}, 0.5 \mathrm{~h}$. 


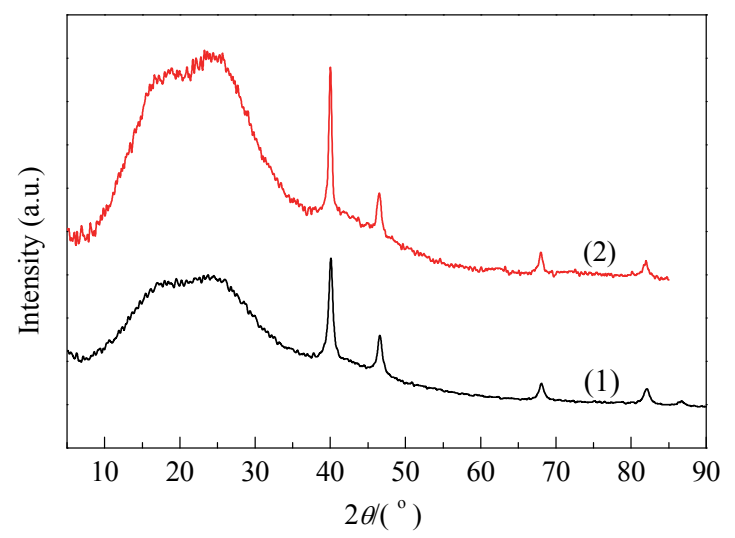

Fig. 6. XRD patterns of $\mathrm{Pd}(2.7) / \mathrm{A}-45$ before (1) and after (2) six recycles.

a series of Pd/A-45 catalysts with different Pd loadings were prepared and compared for the hydrogenation of phenol to cyclohexanone at $60{ }^{\circ} \mathrm{C}$. The crystallite sizes of Pd in these catalysts were calculated using the half-width of the $\mathrm{Pd}(111)$ peak and the Scherrer equation and were summarized in Table 5. At a constant phenol/Pd ratio in feed, the conversion of phenol decreased from 100\% over Pd(0.1)/A-45 (5.0 nm sized Pd NPs) to $44.5 \%$ over $\mathrm{Pd}(4.5) / \mathrm{A}-45$ (14.5 $\mathrm{nm}$ sized Pd NPs), but the selectivity for cyclohexanone reached a maximum value (91.0\%) over $\mathrm{Pd}(2.7) / \mathrm{A}-45$ (12.0 nm sized Pd NPs). At the same time, the turnover frequency (TOF) on the basis of surface $\mathrm{Pd}$ atoms reached 116-118 $\mathrm{h}^{-1}$ over the catalysts with a particle size of $\mathrm{Pd}$ in 9-13 nm (in $\mathrm{Pd}(0.9) / \mathrm{A}-45, \mathrm{Pd}(1.8) / \mathrm{A}-45$, and $\mathrm{Pd}(2.7) / \mathrm{A}-45)$. This volcano shaped TOF versus $\mathrm{Pd}$ particle size curve and the higher selectivity for cyclohexanone over $\mathrm{Pd}(2.7) / \mathrm{A}-45$ indicated that the formation of cyclohexanone was a structure sensitive reaction, and Pd particles of 12-14 $\mathrm{nm}$ were better for their high selectivity.

\section{Conclusions}

Pd NPs were deposited on A-45 resin by a convenient method. The obtained Pd/A-45 catalyst was highly active, selective, and stable for the hydrogenation of phenol to cyclo-

\section{Table 5}

Performance of Pd/A-45 with different Pd loadings.

\begin{tabular}{|c|c|c|c|c|c|c|}
\hline \multirow{2}{*}{$\begin{array}{l}\text { Pd } \\
\text { loading } \\
\text { (wt\%) } \\
\end{array}$} & \multirow{2}{*}{$\begin{array}{l}\text { Size } \\
(\mathrm{nm})\end{array}$} & \multirow{2}{*}{$\begin{array}{c}\text { Conversion } \\
(\%)\end{array}$} & \multicolumn{2}{|c|}{ Selectivity (\%) } & \multirow{2}{*}{$\begin{array}{l}D^{\text {a }} \\
(\%)\end{array}$} & \multirow{2}{*}{$\begin{array}{l}\mathrm{TOF}^{\mathrm{b}} \\
\left(\mathrm{h}^{-1}\right)\end{array}$} \\
\hline & & & $\begin{array}{c}\text { Cyclohexa- } \\
\text { none }\end{array}$ & $\begin{array}{c}\text { Cyclohexa- } \\
\text { nol }\end{array}$ & & \\
\hline$\overline{0.1}$ & 5.0 & 100.0 & 6.3 & 93.7 & 19.4 & 80 \\
\hline 0.3 & 6.3 & 95.5 & 21.5 & 78.5 & 15.4 & 96 \\
\hline 0.6 & 7.7 & 90.3 & 42.2 & 57.8 & 12.6 & 111 \\
\hline 0.9 & 9.0 & 82.5 & 65.7 & 34.3 & 10.8 & 118 \\
\hline 1.8 & 10.9 & 67.1 & 77.6 & 22.4 & 8.9 & 116 \\
\hline 2.7 & 12.0 & 60.2 & 91.0 & 9.0 & 8.1 & 116 \\
\hline 3.6 & 13.6 & 50.0 & 90.2 & 10.8 & 7.2 & 108 \\
\hline 4.5 & 14.5 & 44.5 & 89.8 & 10.2 & 6.7 & 103 \\
\hline
\end{tabular}

Reaction conditions: phenol $0.5 \mathrm{mmol}$, water $20 \mathrm{~mL}$, phenol/Pd ratio 8.0, $60{ }^{\circ} \mathrm{C}, 0.5 \mathrm{~h}, \mathrm{H}_{2} 1.0 \mathrm{MPa}, 1000 \mathrm{r} / \mathrm{min}$.

a Dispersion of Pd calculated as $D=0.97 /$ particle size in $\mathrm{nm}$.

b Turnover frequency defined as (converted phenol molecules at 0.5 h) $/($ (number of surface Pd atoms $) \times($ reaction time, $h))$. hexanone in water under mild conditions $\left(40-100{ }^{\circ} \mathrm{C}, 0.2-1\right.$ $\mathrm{MPa}$ ). The selectivity for cyclohexanone remained higher than $89 \%$ even at complete conversion of phenol. A low pressure is more favorable for the formation of cyclohexanone. These results showed the potential of Pd/A-45 for practical application.

\section{References}

[1] H. Z. Liu, T. Jiang, B. X. Han, S. G. Liang, Y. X. Zhou, Science, 2009, $326,1250$.

[2] Y. Wang, J. S. Zhang, X. C. Wang, M. Antonietti, H. R. Li, Angew. Chem. Int. Ed., 2010, 49, 3356.

[3] U. Schuchardt, D. Cardoso, R. Sercheli, R. Pereira, R. S. da Cruz, M. C. Guerreiro, D. Mandelli, E. V. Spinace, E. L. Fires, Appl. Catal. A, 2001, 211, 1.

[4] S. G. Shore, E. Ding, C. Park, M. A. Keane, J. Mol. Catal. A, 2004, 212, 291.

[5] Y. Li, X. Xu, P. F. Zhang, Y. T. Gong, H. R. Li, Y. Wang, RSC Adv., 2013, 3, 10973.

[6] H. J. Wang, F. Y. Zhao, S. I. Fujita, M. Arai, Catal. Commun., 2008, 9 , 362.

[7] N. Mahata, V. Vishwanathan, J. Catal., 2000, 196, 262.

[8] G. Neri, A. M. Visco, A. Donato, C. Milone, M. Malentacchi, G. Gubitosa, Appl. Catal. A, 1994, 110, 49.

[9] S. Scire, S. Minico, C. Crisafulli, Appl. Catal. A, 2002, 235, 21.

[10] J. R. Gonzalez-Velasco, M. P. Gonzalez-Marcos, S. Arnaiz, J. I. Gutierrez- Ortiz, M. A. Gutierrez-Ortiz, Ind. Eng. Chem. Res., 1995, 34, 1031.

[11] L. Calvo, M. A. Gilarranz, J. A. Casas, A. F. Mohedano, J. J. Rodriguez, Appl. Catal. B, 2006, 67, 68.

[12] J. F. Zhu, G. H. Tao, H. Y. Liu, L. He, Q. H. Sun, H. C. Liu, Green Chem., 2014, 16, 2664.

[13] S. T. Srinivas, L. Jhansi Lakshmi, P. Kanta Rao, Appl. Catal. A, 1994, 110, 167.

[14] A. K. Talukdar, K. G. Bhattacharyya, S. Sivasanker, Appl. Catal. A, 1993, 96, 229.

[15] T. T. Bovkun, Y. Sasson, J. Blum, J. Mol. Catal. A, 2005, 242, 68.

[16] E. J. Shin, M. A. Keane, Ind. Eng. Chem. Res., 2000, 39, 883.

[17] G. Yuan, J. Llanos Lopez, C. Louis, L. Delannoy, M. A. Keane, Catal. Commun., 2005, 6, 555.

[18] H. Li, J. Liu, S. H. Xie, M. H. Qiao, W. L. Dai, Y. F. Lu, H. X. Li, $A d v$. Funct. Mater., 2008, 18, 3235.

[19] P. Makowski, R. Demir Cakan, M. Antonietti, F. Goettmann, M. M. Titirici, Chem. Commun., 2008, 999.

[20] J. Morales, R. Hutcheson, C. Noradoun, I. F. Cheng, Ind. Eng. Chem. Res., 2002, 41, 3071.

[21] S. Velu, M. P. Kapoor, S. Inagaki, K. Suzuki, Appl. Catal. A, 2003, $245,317$.

[22] J. Y. He, C. Zhao, J. A. Lercher, J. Catal., 2014, 309, 362.

[23] H. L. Liu, Y. W. Li, R. Luque, H. F. Jiang, Adv. Synth. Catal., 2011, 353, 3107.

[24] D. M. Zhang, Y. J. Guan, E. J. M. Hensen, L. Chen, Y. M. Wang, Catal. Commun., 2013, 41, 47.

[25] L. Cheng, Q. G. Dai, H. Li, X. Y. Wang, Catal. Commun., 2014, 57, 23.

[26] H. Yoshida, S. Narisawa, S. I. Fujita, M. Arai, J. Mol. Catal. A, 2013, $379,80$.

[27] Y. Wang, J. Yao, H. R. Li, D. S. Su, M. Antonietti, J. Am. Chem. Soc., 2011, 133, 2362.

[28] S. Watanabe, V. Arunajatesan, Top. Catal., 2010, 53, 1150.

[29] W. C. Du, S. X. Xia, R. F. Nie, Z. Y. Hou, Ind. Eng. Chem. Res., 2014, 53, 4589.

[30] D. D. Zhang, D. L. Wei, Q. Li, X. Ge, X. F. Guo, W. P Ding, Z. K. Xie, Sci. 


\title{
Graphical Abstract
}

Chin. J. Catal., 2016, 37: 234-239 doi: 10.1016/S1872-2067(15)60997-4

Selective hydrogenation of phenol to cyclohexanone in water over Pd catalysts supported on Amberlyst-45

Mengsi Zhao, Juanjuan Shi, Zhaoyin Hou*

Zhejiang University

Ion-exchange resin Amberlyst-45 supported Pd nanoparticles was highly active and selective for the selective hydrogenation of phenol to cyclohexanone in water under mild conditions $\left(40-100{ }^{\circ} \mathrm{C}, 0.2-1 \mathrm{MPa}\right)$.

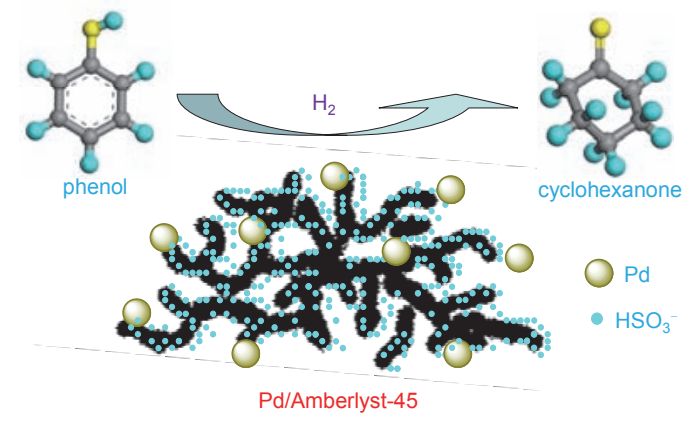

Rep., 2014, 4, 4021.

[31] K. R. Priolkar, P. Bera, P. R. Sarode, M. S. Hegde, S. Emura, R. Kumashiro, N. P. Lalla, Chem. Mater., 2002, 14, 2120.

[32] V. Z. Radkevich, T. L. Senko, K. Wilson, L. M. Grishenko, A. N. Zaderko, V. Y. Diyuk, Appl. Catal. A, 2008, 335, 241.
[33] C. V. Rode, U. D. Joshi, O. Sato, M. Shirai, Chem. Commun., 2003, 1960.

[34] S. Kale, S. B. Umbarkar, M. K. Dongare, R. Eckelt, U. Armbruster, A. Martin, Appl. Catal. A, 2015, 490, 10.

[35] H. Sakurai, K. Koga, M. Kiuchi, Catal. Today, 2015, 251, 96.

\section{Pd/Amberlyst-45催化剂催化水相中苯酚选择性加氢制环己酮}

\author{
赵梦思, 石娟娟, 侯昭胤 ${ }^{*}$ \\ 浙江大学化学系催化研究所, 浙江杭州 310028
}

摘要: 环己酮是重要的有机化工原料和工业溶剂, 是制造尼龙、己内酰胺和己二酸的主要中间体, 环己酮的绿色生产工艺受到人 们关注. 目前全世界环己酮年产量接近 900 万吨, 但环己酮生产仍主要以环己烷为原料, 采用富氧空气氧化为环己基过氧化氢, 再 在铬酸叔丁醌催化剂作用下分解为环己醇和环己酮的混合物, 然后经一系列蒸馏精制后得到环己酮, 工艺复杂, 能耗高, 而且设备 腐蚀、环境污染及安全问题严重. 因此, 大量工作正致力于新工艺和新催化剂研究, 其中光催化氧化、分子筛催化氧化和金属氧 化物催化氧化等都有相关报道, 同时还有学者开发了其它环己酮制备新方法, 如环己烯水合法、苯加氢法、环己醇氧化法和苯酚 加氢法等.

苯酚直接选择性加氢合成环已酮研究具有重要意义. 苯酚加氢通常有两种工艺, 气相加氢和液相加氢, 由于液相加氢具有无 需将反应物汽化、能耗较低和催化剂反应活性高等优势而受到广泛关注. 但是目前大量文献报道的苯酚加氢过程仍需要高温条 件且较易产生环己醇和环己烷等副产物, 大部分催化反应需在有机溶剂中进行, 因此如何提高环已酮选择性, 减小环境影响成为 近年来的热门课题. 在过去数年中, 人们篎选了大量催化剂, 其中Pd催化剂具有较高活性和目的产物选择性, 因为其对羰基表现 出较低的催化活性. 研究还发现, 催化剂载体对苯酚加氢产物分布有重要影响, 酸性载体或酸性助剂的加入均能提高苯酚转化率 和环己酮选择性, 可能的原因是催化剂表面可与苯酚羟基形成 $\mathrm{O}-\mathrm{H} \cdots \pi$ 强相互作用, 使苯酚分子更容易吸附在载体表面, 而一旦苯 酚经催化加氢生成环己酮, 由于失去羟基与载体表面相互作用, 环己酮更容易从载体表面脱附, 从而避免过度加氢生成环己醇, 同 时酸性位点可以增强Pd的电子密度, 提高催化加氢活性. 另外, 通过添加助剂也可有效改善催化剂性能. 然而, 到目前为止, 通过 单一的一种催化剂仍然很难同时实现苯酚的高转化率和环己酮的高选择性. 因此, 开发新催化剂和简便的生产工艺对环己酮高 效高质量生产具有重要意义.

本文使用一种多孔、不易溶解的酸性离子交换树脂Amberlyst-45 (A-45)为载体, 采用简单的浸渍工艺制备了一系列不同 $\mathrm{Pd}$ 负 载量的 Pd/A-45催化剂, 详细考察了催化剂在水相中对苯酚选择性加氢制环己酮的催化活性和选择性, 包括反应温度、催化剂用 量、反应时间和Pd负载量等对反应活性的影响及催化剂重复使用情况, 并且与传统的 $\mathrm{SiO}_{2}, \mathrm{ZnO}, \mathrm{MgO}, \mathrm{Al}_{2} \mathrm{O}_{3}$ 和活性炭负载的 $\mathrm{Pd}$ 催 化剂进行对比. 研究发现, Pd/A-45催化剂在温和反应条件 (40-100 $\left.{ }^{\circ} \mathrm{C}, 0.2-1 \mathrm{MPa}\right)$ 下具有极高的催化活性和选择性, 在适宜的反应 条件下苯酚转化率达到 $100 \%$, 环己酮选择性高于 $89 \%$. 进一步分析由不同活性金属负载量制备的不同粒径 $\mathrm{Pd} / \mathrm{A}-45$ 催化剂的活性 规律发现, 苯酚加氢生成环己酮是一个结构敏感型反应, 其中Pd颗粒尺寸为12-14 nm时更有利于环已酮生成.

关键词: 苯酚; 加氢; 环己酮; 钯; Amberlyst-45树脂; 负载型催化剂

收稿日期: 2015-09-03. 接受日期: 2015-09-29. 出版日期: 2016-02-05.

*通讯联系人. 电话/传真: (0571)88273283; 电子信箱: zyhou@zju.edu.cn

基金来源：国家自然科学基金(21473155, 21273198, 21073159); 浙江省自然科学基金( LZ12B03001).

本文的英文电子版由Elsevier出版社在ScienceDirect上出版(http://www.sciencedirect.com/science/journal/18722067). 